\title{
Impact of Work Environmental Factors on Job Performance, Mediating Role of Work Motivation: A Study of Hotel Sector in England
}

\author{
Thushel Jayaweera ${ }^{1}$ \\ ${ }^{1}$ Facult of Social Sciences, University of Bristol, UK \\ Correspondence: Thushel Jayaweera, Facult of Social Sciences, University of Bristol, UK. E-mail: \\ thusheljayaweera@gmail.com
}

Received: August 4, 2014

Accepted: November 25, 2014

Online Published: February 27, 2015

doi:10.5539/ijbm.v10n3p271

URL: http://dx.doi.org/10.5539/ijbm.v10n3p271

\begin{abstract}
The study tested the relationship between work environmental factors and job performance with work motivation and the extent to which this relationship is mediated by work motivation among a sample of hotel workers in England. In this cross-sectional study, a questionnaire survey was conducted among 254 hotel workers at twenty-five chain hotels in Bristol, England. The results suggest that there is a significant relationship between work environmental factors and job performance and that work motivation mediates the relationship between working conditions and job performance. The results also suggest that there is a significant relationship between work motivation and job performance of the hotel workers. The results point to the importance of working conditions and work motivation in explaining job performance of hotel workers in the framework of work environmental conditions and job performance. The limitations and implications and the study are also discussed.
\end{abstract}

Keywords: Work environmental factors; hotel workers, motivation, job performance

\section{Introduction}

Job performance is a very significant factor affecting profitability of an organization (Bevan, 2012). Inefficient job performance will bring about a tragedy to the organization as associated with lower productivity, profitability and impairment of overall organizational effectiveness (Cooke, 2000; Okoyo \& Ezejiofor, 2013). As pointed out by Viswesvaran and Ones (2000), job Performance is the core construct of today's work place. Job performance is defined as behaviors or activities that are performed towards achieving the organization's goals and objectives (Motowidlo, Borman, \& Schmit, 1999). Performance is important for organizations as employee performance leads to business success and performance is important for individual as accomplishing tasks can be a source of satisfaction (Muchhal, 2014).

Existing research has established a link between working conditions and job performance (Fine \& Kobrick, 1978; Mohapatra \& Srivastava, 2003; Naharuddin \& Sadegi, 2013, Brill, Margulis, \& Konar, 1985; Naharuddin \& Sadegi, 2013; Chandrasekarr, 2011; Dolden \& Ward, 1986; Davis, 1984; Vischer, 2008). Having the right environmental factors both physical and psychosocial will lead to increase performance (Buhter, 1997; Chandrasekar, 2011). Khan et al. (2011) investigated in their study the impact of workplace environment and infrastructure on employees' performance among a sample of 150 respondents from the education sector in Pakistan and concluded that incentives at workplace had a positive impact on employee's performance while infrastructure at workplace had no significant impact on employees. A large number of work environmental studies have been conducted in office environments. For example, one study suggested the management should make an additional investment in ergonomic tables and chairs to enhance worker's productivity (Miles, 2000). Additionally, some studies have examined the impact of work environmental factors such as the height and thickness of workstation partitions, furniture measurements and the amount and availability of file and work storage on individual and team performance (Visher 2008). Kahya's (2007) study concluded that there is an impact of job characteristics and working conditions on job performance in a manufacturing setting. Studies in the context of hotel sector have shown that working conditions in the hotel sector are poor (Wight \& Pollert, 2006). Yet, no study has been conducted to examine the environmental conditions on job performance in the context of hotel workers in Britain, to the best of researcher's knowledge so far. With regard to the hotel sector 
jobs, environmental conditions range from ordinary to extreme conditions in terms of the factors such as heat, humidity, noise, smell, light, and dust. Identifying the impact of work environment on job performance of hotel employees will contribute to understand ways in which managers can enhance job performance of workers. Therefore, in an attempt to fill this research gap, this study investigates the impact of work environment factors on performance related matters within the context of hotel sector in Britain.

One of the most known constructs of job performance adds to the association between motivation and job performance. Motivation directs certain behavior toward achieving a specific goal (Sansone \& Harackiewicz, 2000). Previous research have demonstrated that motivate employees are inclined to be more productive than non-motivated employees (Chaudhary \& Sharma, 2012; Afful-broni, 2012). Aisha and colleague's (2013) found that the variables incentives, motivation and working conditions have a significant effect on employee performance in an Indonesian university. Previous studies have also examined the impact of moderating and mediating role of motivation on workplace characteristics and outcomes relationship. Therefore, scholars have suggested that more research on mediating variables in workplace conditions and outcome studies are needed (Carr, Schmidt, Ford, \& Deshon, 2003; Ostroff, 2003). For example, Kuvaas (2006) found that intrinsic motivation both moderated and mediated the relationship between performance appraisal satisfaction and work performance. Also, Geister and Hertel (2006) found that initial motivation moderated the online feedback-performance improvement relationship. Guo and colleague's study (2014) examined the mediating role of intrinsic motivation on the relationship between developmental feedback and employee job performance. Barrick, Stewart and Piotrowski (2002) tested a model that examines the mediating effect of motivation on the relationship between personality traits and performance in a sales job. Parker and colleague's (2003) tested the mediating role of motivation in a combination of several studies. In light of the above empirical evidence presented, I propose that motivation may act as a moderator in the work environment and job performance relationship. Therefore, the model in the current study is a mediate one where it is proposed that motivation act as mediator: "mediators explain how external events take on internal psychological significance" (Baron and Kenny, 1986). The mediating effect of motivation on the relationship between work environmental factors and Job performance has not been examined in previous researches. The aim of this study was to test the relationship between work environmental factors and job performance (e.g., task and contextual performance) with work motivation and the extent to which this relationship is mediated by work motivation among a sample of hotel workers in the Great Britain. The study proposed to test a probable unified hypothesis: motivation, as a very conspicuous and handy factor in the context of hotel workers, is an essential functional [or buffer] link between physical work conditions and the final outcome from job performance.

\section{Methodology}

\subsection{Measures}

\subsubsection{Background Variables}

This section of the questionnaire asked questions about sex, age (a five-point response scale), educational qualification, job position, years of employment in the hotel and in the hotel sector (a five-point response scale). All participants responded to a questionnaire concerning background variables.

\subsubsection{Work Environmental Factors}

The domain of work environment contains two parts: physical and psychosocial working conditions (Arsalani et al., 2011). A questionnaire was developed using the physical items to quantify specific heavy lifting, bending/uncomfortable posture and prolonged standing position within the hotel profession taken from the report "Protecting workers in hotels, restaurants and catering" (2008) published by the European Agency for Safety and Health at Work. The scale was a five point likert scale, with scores ranging from 1 to 5 , the higher scores indicated higher exposure.

Psychosocial working conditions were measured using a modified version of the medium-length version of the COPSOQ-I questionnaire that contains 11 subscales: quantitative demands, emotional demands, influence at work, meaning of work, role clarity, quality of leadership, sense of community, insecurity at work, job satisfaction and two scales for measuring general health and mental health (Kristensen et al., 2005). The scales measuring general health and mental health were excluded for the current study. Participants were asked to indicate on a Likert-type scale ranging from 1 (strongly disagree) to 5 (strongly agree).

\subsubsection{Work Motivation}

Work motivation was measured using the 18-item WEIMS. The scale WEIMS contains 18 items and assesses six types of motivation postulated by SDT (i.e., intrinsic motivation, integrated, identified, introjected and 
external regulations, and amotivation). Participants were asked to indicate on a Likert-type scale ranging from 1 (does not correspond at all) to 5 (corresponds exactly) the extent to which the items represent the reasons they are presently involved in their work.

\subsubsection{Job Performance}

Task performance: As a part of this research, a sample of hotel managers were asked to identify the appropriate criteria for measuring task based job performance based on hotel's job analysis. Job knowledge, physical ability to carry duties, communication skills, teamwork skills, punctuality and concentrating to duties were identified as important criteria for measuring job performance based on the results of the job analysis. In addition, four of the criteria developed by Motowidlo and Van Scotter (1994) were included. Managers were asked to rate the job performance of their workers on a five-point Likert scale ranging from (1) very poor to (5) excellent.

Contextual performance: A questionnaire was developed based on the sixteen items of contextual performance identified by Borman and Motowidlo (1993). Managers were asked to rate the job performance of their workers on a five-point Likert scale ranging from (1) very poor to (5) excellent. It was guaranteed that their responses would remain completely confidential. All of the managers completed the performance rating questionnaires for all their employees.

\subsection{Samples and Data Collection Method}

A questionnaire was distributed to hotel workers who were randomly selected from 25 hotels in Bristol in this cross sectional study. The questionnaire was distributed among 600 workers but received 254 questionnaires. The questionnaire included a letter that explained the purpose of the survey and guaranteed confidentiality. These responding subjects were also sent reminders and requested that each question answered in order for the questionnaire to be considered complete, ensuring there were no missing data.

\subsection{Ethical Considerations}

The research proposal was approved by the Ethics Committee of the University of Bristol, United Kingdom. Permission was granted from the managers of the chosen hotels to conduct this survey. Further, permission and written consent have been obtained from all participants and they were given information about the aim of the study. Before filling in the questionnaires, all participants were informed that participation was anonymous, and that they could terminate their participation at any time during the study.

\section{Results}

\subsection{Reliability Test}

Table 1 shows the Cronbach's Alpha for the independent variables and also for the dependent variables. The closer the Cronbach's Alpha is to 1, the higher the internal consistency reliability. As point out by Sekaran (2003), the reliability that is less than 0.60 is considered as poor and if it is in the range of 0.70 , it is considered as acceptable. As for those, which are more than 0.80 , is it considered as good.

The analysis shows that the Cronbach Alpha for the job performance is 0.936 , for physical work environmental factors is 0.942 , for psychosocial environment is 0.961 and for motivation is 0.954 . Accordingly, all of the variables are considered as good because they are more than 0.8 .

Table 1 . The reliability analysis for independent and dependent analysis

\begin{tabular}{llll}
\hline Variable & & Number of Items & Cronbach's Alba \\
\hline Job Performance & & 22 & 0.936 \\
Physical Work & environmental & 08 & 0.942 \\
Factors & & & \\
Psychosocial & Environmental & 15 & 0.961 \\
Factors & & 18 & 0.954 \\
Motivation & & & \\
\hline
\end{tabular}

\subsection{Descriptive Analysis and Correlational Analysis}

The demographic results of the respondents gained by the questionnaires of this study are presented in the figure 1. According to the figure 1, the percentage of the male respondent is 69.29 . Meanwhile, as for the female respondent, the percentage is lower with 30.70 percent. Majority of the respondent were aged less than 30 years with 77.94 percent. In terms of qualifications, majority of the respondents were educated at the 
Secondary school level with 56.29 percent. According to the table, it shows that most of the respondents were either married, cohabiting or in a relationship $(59.44 \%)$. In terms of the number of years of service, majority of the respondents worked less than a year $(76.77 \%)$ and the largest number of the respondent comes from the European Union (55.90\%).

The descriptive analyses for the research variables are presented in the Table 2 . The mean value of these variables is in between 3.10 to 3.24. A standard deviation measures the dispersion value that point to the gap between one respondent to another respondent. When the value of the standard deviation is smaller, it is considered as good. According to table 3, the highest standard deviation is recorded in the psychosocial work environment (1.09). Meanwhile the lowest is the motivation with 0.68 . The correlations analysis was used to inspect the relationship between all the variables in the research model. The result shows several interesting findings. Physical work environmental factors were strongly correlated with job performance $(0.542 \mathrm{p}<.01)$. A significant relationship can be seen between the psychosocial environmental factors and job performance $(\mathrm{r}=$ $0.481)$. A similar result has been reported between motivation and job performance $(\mathrm{r}=0.511)$.

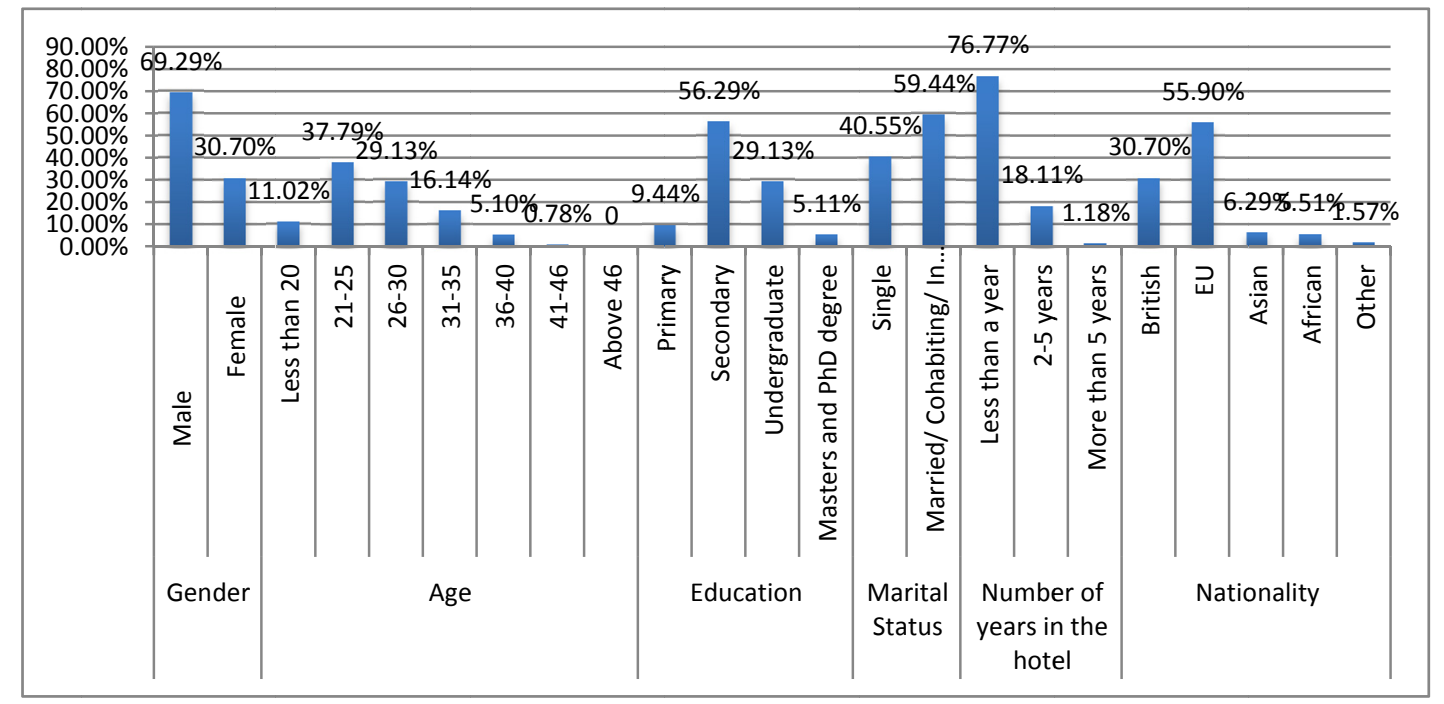

Figure 1. Demographic statistics

Table 3. Mean and standard deviation and correlations of the study variables

\begin{tabular}{lcllllll}
\hline & $\mathrm{N}$ & Mean & Std. Deviation & 1 & 2 & 3 & 4 \\
\hline $\begin{array}{l}\text { Job Performance } \\
\text { Physical }\end{array}$ & 254 & 3.24 & 0.77 & - & & & \\
$\begin{array}{l}\text { Environment } \\
\text { Work }\end{array}$ & & & & & & & \\
Psychosocial & 254 & 3.19 & 0.94 & $0.542^{* *}$ & - & & \\
Environment & & & & $0.481^{* *}$ & 0.071 & - & - \\
Motivation & 254 & 3.12 & 0.99 & $0.511^{* *}$ & 0.111 & 0.165 & - \\
& 254 & 3.10 & 0.68 & & & & \\
\hline
\end{tabular}

Note. ${ }^{* *}$ Correlation is significant at the 0.01 level (2-tailed).

\subsection{Hierarchical Regression Analysis}

A hierarchical regression analysis was conducted to examine the effect of work environmental factors (physical work environmental factors, psychosocial work environmental factors) on job performance and to test whether or not motivation mediates the relationship between work environmental factors and job performance relationship.

Table 4 shows the results of hierarchical regression analysis. The results of Model 2 show a significant $\mathrm{ch}$ ange in R-squared value. In other words, R-square increased from 0.971 to 0.977 . The results show that once the mediating variable is entered, the strength of the relationship between work environmental factors and job performance has reduced. Therefore, the hypothesis that motivation, as a very conspicuous and handy factor in 
the context of hotel workers, is an essential functional [or buffer] link between physical work conditions and the final outcome from job performance is supported.

Table 4. Results of hierarchical regression analysis

\begin{tabular}{llllllll}
\hline Step & Dependent Variable & Independent Variable & beta & t-value & Sig & F Value & R square \\
\hline 1 & JP & Physical environment & 0.341 & 18.32 & $<0.01$ & 1403.645 & 0.971 \\
& & Psychosocial environment & 0.272 & 13.63 & & & \\
2 & \multirow{2}{*}{ JP } & Physical environment & 0.294 & 16.76 & $<0.01$ & 1361.552 & 0.977 \\
& & Psychosocial environment & 0.256 & 13.51 & & & \\
& & Motivation & 0.095 & 5.97 & & & \\
\hline
\end{tabular}

\section{Discussion, Limitations and Implications of the Study}

In conclusion, the significant findings of this study can be highlighted as below: (a) Environmental conditions significantly affected job performance. The results are consistent with the previous studies showing an association between working environment and job performance (Fine \& Kobrick,1978; Mohapatra \& Srivastava, 2003; Naharuddin \& Sadegi, 2013). It implies managers and supervisors must consider improving work environment while considering both physical and psychosocial factors to promote job performance of their staff. (b) Motivation has a significant effect on job performance and the findings are consistent with the previous research findings (Lyons, Duxbury, \& Higgins 2006; Maidani 1991; Cerasoli et al., 2014). It reveals that employees perform better when they are motivated. It means that the management must take initiatives to promote motivation among workers, both intrinsically and extrinsically by provide increments in pay and benefits and acknowledging employee perspectives and encouraging initiatives; (c) motivation holds a mediating effect between the relationship between working conditions and job performance. This suggests that those workers who perceive working conditions to be poor or bad are less motivated and consequently are not performing satisfactory.

The participants of the study held different jobs within the hotels. The data was not collected on the participant's job title. It is likely that that there are variations with regard to working conditions and job performance across different job titles. Therefore, it is recommended that future studies examine the relationship between work and job performance across different job titles. This study was limited and only focused on the role of environmental conditions, work motivation on job performance of hotel workers in 20 selected hotels in Bristol, United kingdom. Further research is suggested to collect data over a wider range like the employees of the different departments of the hotel sector overall in Britain to make sure if the findings of this study can be generalized. A further research can also be conducted on the effect of personality, which is found to be effective on job performance in many researches.

The study shows that job performance is very much influenced by work environment and motivation of workers. The study also confirms the mediating role of motivation in working conditions and job performance relationship within regard to hotel workers. Hotel industry needs to consider improving its environmental factors and ways to improve work motivation to boost employee performance.

Similar to the work of Kahya (2007), the present research provides evidence that it is helpful to consider the impact of motivation on job performance while taking motivation into account. With regard to motivation, good working conditions will enhance motivation of workers. Considering the positive impact of work place environmental characteristics and work motivation on job performance, it is suggested that the management should take initiatives to motivate employees and improve work environments. As employees have motivation, their job performance will increase. The present findings show that working conditions can predict job performance better when individuals are motivated toward the job; that is, when they are wanting to achieve the desired outcomes and goals of the job. In any case, I hope that motivation will turn out to be a valuable mediate and moderate variable in future job performance research.

\section{References}

Afful-Broni, A. (2012). Relationship between motivation and job performance at the University of mines and technology, Tarkwa, Ghana. Leadership lessons, Creative Education, 3(3), 309-314. http://dx.doi.org/10.4236/ce.2012.33049 
Aiken, L. S., \& West, S. G. (1991). Multiple regression: Testing and interpreting interactions. Newbury Park: Sage.

Aisha, A. N., Hardjomidjojo, P., \& Yassierli. (2013). Effects of Working Ability, Working Condition, Motivation and Incentive on Employees Multi-Dimensional Performance. International Journal of Innovation, Management and Technology, 4(6). http://dx.doi.org/10.7763/IJIMT.2013.V4.470

Arsalani, N., Fallahi-khoshknab, M., Ghaffari, M., Josephson, M., \& Lagerstrom, M. (2011). Adaptation of Questionnaire Measuring Working Conditions and Health Problems Among Iranian Nursing Personnel. Asian Nursing Research, 5(3), 177-182. http://dx.doi.org/10.1016/j.anr.2011.09.004

Baron, R., \& Kenny, D. (1986). The moderator-mediator variable distinction in social psychological research: Conceptual, strategic, and statistical considerations. Journal of Personality and Social Psychology, 51, 1173-1182. http://dx.doi.org/10.1037/0022-3514.51.6.1173

Barrick, M. R., Greg, L. S., \& Mike, P. (2002). Personality and Job Performance: Test of the Mediating Effects of Motivation among Sales Representatives. Journal of Applied Psychology, 87(1), 43-51. http://dx.doi.org/10.1037/0021-9010.87.1.43

Bevan, S. (2012). Good work, High performance and productivity. The paper prepared for the European HRD Forume, Lisbon, 2012, Retrieved from http://www.theworkfoundation.com/DownloadPublication/Report/316_Good\%20Work\%20High\%20Per formance\%20and\%20Productivity.pdf

Borman, W. C., \& Motowidlo, S. J. (1993). Expanding the criterion domain to include elements of contextual performance. In N. Schmitt \& W. C. Borman (Eds.), Personnel selection in organizations (pp. 71-98). San Francisco, CA: Jossey Bass.

Brill, M., Margulis, S., \& Konar, E. (1985). Using office design to increase productivity (2nd ed.). Buffalo, NY: Westinghouse.

Buhter, P. (1997), Scanning the environment, environmental trends affecting the workplace. Supervision Publications, 1-2.

Carr, J. Z., Schmidt, A. M., Ford, J. K., \& DeShon, R. P. (2003). Climate perceptions matter: A meta-analytic path analysis relating molar climate, cognitive and affective states, and individual level work outcomes. Journal of Applied Psychology, 88, 605-619. http://dx.doi.org/10.1037/0021-9010.88.4.605

Cerasoli, C. P., Nicklin, J. M., \& Ford, M. T. (2014). Intrinsic motivation and extrinsic incentives jointly predict performance: A 40-year meta-analysis. Psychological Bulletin, 140(4), 980-1008. http://dx.doi.org/10.1037/a0035661

Chandrasekar, K. (2011). Workplace environment and its impact on organisational performance in public sector organizations. International Journal of Enterprise Computing and Business System, 1(1), 1-20.

Chaudhary, N., \& Sharma, B. (2012). Impact of Employee Motivation on Performance (Productivity) In Private Organization. International Journal of Business Trends and Technology, 2(4).

Cooke, F. L. (2000). Human Resource Strategy to improve Organizational performance: A route for British Firms. Working paper no.9, ESRC Future of work Programme. Retrieved from http://www.leeds.ac.uk/esrcfutureofwork/downloads/workingpaperdownloads/paper9.pdf

Davis, T. R. V. (1984). The Influence of the Physical Environment in Offices.

Dolden, M., \& Ward, R. (1986). The impact of the work environment on productivity: Proceedings of a workshop. Washington, DC: National Science Foundation and Architectural Research Centers Consortium.

Fine, B. J., \& Kobrick, J. L. (1978). Effects of attitude and heat on complex cognitive tasks. Human Factors, 20, $115-122$.

Geister, S., \& Hertel, G. (2006). Effects of Process Feedback on Motivation, Satisfaction, and Performance. In Virtual Teams, Gerber HP, McMurtrey A, Kowalski J, Yan M, Keyt BA, Dixit V., \& Ferrara N. (Eds.), J. Biol. Chem. 273.

Guo, Y., Liao, J., Liao, S., \& Zhang, Y. (2014). The mediating role of intrinsic motivation on the relationship between developmental feedback and employee job performance. Social Behaviour and personality, 42(5). http://dx.doi.org/10.2224/sbp.2014.42.5.731 
Kahya, E. (2007). The effects of job characteristics and working conditions on job performance. International Journal of Industrial Ergonomics, 37, 515-523. http://dx.doi.org/10.1016/j.ergon.2007.02.006

Khan, S. H., Azhar, Z., Parveen, S., Naeem, F., \& Sohail, M. M. (2011). Exploring the impact of infrastructure, pay incentives, and workplace environment on employees performance (A case study of Sargodha University). Asian Journal of Empirical Research, 2(4), 118-140.

Kristensen, T. S., Hannerz, H., Hogh, A., \& Borg, V. (2005). The Copenhagen psychosocial questionnaire-A tool for the assessment and improvement of the psychosocial work environment. Scand J Work Environ Health, 31(6), 438-449. http://dx.doi.org/10.5271/sjweh.948

Kuvaas, B. (2006). Performance appraisal satisfaction and employee outcomes: mediating and moderating roles of motivation. The International Journal of Human Resource Management, 17(3), 504-522. http://dx.doi.org/10.1080/09585190500521581

Lyons, S. T., Duxbury, L. E., \& Higgins, C. A. (2006). A comparison of the values and commitment of private sector, public sector, and parapublic sector employees. Public Administration Review, 66(4), 605-618. http://dx.doi.org/10.1111/j.1540-6210.2006.00620.x

Maidani, E. A. (1991). Comparative study of Herzberg's two-factor theory of job satisfaction among public and private sectors. Public Personnel Management, 20(4), 441-448.

Miles, A. K. (2000). The Ergonomics and Organizational Stress Relationship ( $\mathrm{PhD}$ thesis). Florida State University School of Business.

Mohapatra, B. K., \& Srivastava, A. K. (2003). A study of the relationship of perceived work environment with job attitude, performance and health. Unpublished PhD. Dissertation, Department of Psychology, Banaras Hindu University.

Motowidlo, S. J., \& Van Scotter, J. R. (1994). Evidence that task performance should be distinguished from

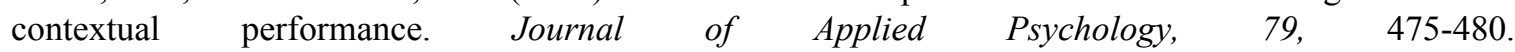
http://dx.doi.org/10.1037/0021-9010.79.4.475

Motowidlo, S. J., Borman, W. C., \& Schmit, M. J. (1999). Performance assessment in unique jobs. In D.R. Ilgen $\&$ E. D. Pulakos (Eds.), The changing nature of performance (pp. 56-86). San Francisco: Jossey-Bass.

Muchhal, D. S (2014). HR Practices and Job Performance. IOSR Journal of Humanities And Social Science (IOSR-JHSS), 19(4), 55-61. http://dx.doi.org/10.9790/0837-19415561

Naharuddin, N. M., \& Sadegi, M. (2013). Factors of Workplace Environment that Affect Employees Performance: A Case Study of Miyazu Malaysia. International Journal of Independent Research and Studies, 2(2), 66-78.

Okoyo, P. V. C., \& Ezejiofor, A. (2013). The effect of Human resource development on Organizational Productivity. International Journal of Academic Research in Business and Social Sciences, 3(10), 250-268.

Ostroff, C., Kinicki, A. J., \& Tamkins, M. M. (2003). Organizational culture and climate. In W. C. Borman, D. R. Ilgen \& R. J. Klimoski (Eds.), Handbook of psychology: Industrial and organizational psychology (Vol. 12, pp. 565-593). John Wiley \& Sons, Inc. http://dx.doi.org/10.1002/0471264385.wei1222

Parker, C. P., Baltes, B. B., Young, S. A., Huff, J. W., Altmann, R. A., Lacost, H. A., et al. (2003). Relationships between psychological climate perceptions and work outcomes: A meta-analytic review. Journal of Organizational Behavior, 24, 389-416. http://dx.doi.org/10.1002/job.198

Sansone, C., \& Harackiewicz, J. M. (2000). Intrinsic and extrinsic motivation: The search for optimal motivation and performance. San Diego, CA: Academic Press.

Sekaran, U. (2003). Research Methods for Business: A Skill Building Approach. New York, NY: John Wiley \& Sons.

Vischer, J. C. (1989). Environmental quality in offices. New York: Van Nostrand Reinhold.

Vischer, J. C. (2008). Towards an environmental psychology of workspace: How people are affected by environments for work. Architectural Science Review. 51(2), 97-108. http://dx.doi.org/10.3763/asre.2008.5114

Visveswaran, C., \& Ones, D. S. (2000). Perspectives on models of job performance. International Journal of Selection and Assessment, (8), 216-226. http://dx.doi.org/10.1111/1468-2389.00151 
Wright, T., \& Pollert, A. (2006). The experience of ethnic minority workers in the hotel and catering industry: Routes to support and advice on workplace problems. Retrieved from http://www.acas.org.uk/media/pdf/e/7/03-06_1-accessible-version-July-2011.pdf

\section{Copyrights}

Copyright for this article is retained by the author(s), with first publication rights granted to the journal.

This is an open-access article distributed under the terms and conditions of the Creative Commons Attribution license (http://creativecommons.org/licenses/by/3.0/). 